abroad has been furnishing students and writers with what was heretofore unattainable. The magnificent library around about us, in so great a degree the outcome of the labors of Dr. Billings, has supplied the material for the work. The high scholarship and peculiar fituess for editorial supervision that have long characterized Dr. Billings and his co-laborer Dr. Fletcher have guaranteed fulness and accuracy of selection and classification: the abundance of clerical aid has secured extraordinary regularity and rapidity of appearance of the successive volumes. A first series completed, a second is bringing the catalogue up to date; and the declaration may safely be made that the Medical Department of the United States Army has accomplished the most gigantic, important and useful medical task known to history. Over and above this literary work it has accumulated stored and scientifically arranged a museum that so far as relates to the diseases and injuries of soldiers is unapproached and in all probability unapproachable.

Keeping in mind the things done, the services rendered, the influence exerted by the officers of the Medical Staff through all these many years, who can rightfully refuse to the Corps full meed of respect, full measure of honor? True, more perhaps might have been accomplished; not a few bright minds have suffererl eclipse; there has been much loitering on the way; but our Country and our profession are and ought to be proud of their most carefully selected body of medical men. Many of its members have gone out into civil life, carrying with them those principles of honor and integrity and devotion to duty that are the very life and soul of an Army Officer. You may well take pride in the labors and the successes of such general practitioners as Heustis and Pitcher and Porter, of such surgeons as Van Buren and Weir and Gouley, of such gynecologists as Homans and Lee, of such oculists as Thomson and Norris and Fryer, of such laryngologist as Asch, such alienist as Cowles, such anatomists as Isaacs and Allen, such chemists and scientists as Torrey and Bache, such zoologists as Coues and Schufeldt. The names of at least twentyfive of the medical teachers in almost as many schools have at one time or another been borne upon your rolls, and among them are those of Bartholow and Dunster and Glison and Pooley.

Thanking your Dean and the Surgeon-General for the honor that they have done me, it is with much pleasure, gentlemen of the Army Medical School, that I congratulate you on the completion of your academic labors and wish you all success in the life that is before you. In having the opportunities for special training here afforded you have been far more fortunate than were your elders. Of all the good work that Surgeon-General Sternberg has done none will prove to have been better than the establishing of this School, and you may be sure that in every effort to increase your scientific knowledge and to add to the sum total of the world's information on matters medical you will have the sympathy and aid of your Chief. Personal experience long aøo taught him how hard it is to make bricks without straw, to follow out in army life careful continued accurate investigations without the support of-more, in the face of the opposition of-the higher officers of the Department. With you, under the present order of things, it will certainly be, the more labor the more favor. Will you pardon me if I suggest to you that while you are military surgeons you are medical men and Medicine is greater than any of her departments. As far as may be possible, put yourselves in close touch with the general and local profession, and as you may freely receive freely give. The long time isolation of the surgeons of the Army has come to an end with the conditions that necessitated the establishment and maintenance of many and widely separated posts. As your duties call you to the vicinity of cities that are, in greater or less measure, medical as well as commercial and political centers, take your places as members of the greater and higher Medical Corps that embraces all the good men and true who are advancing Medicine and benefiting mankind. Again congratulating you, I bid you God speed.

\section{THE RELATION OF THE MEDICAL AND LEGAL DEPARTMENTS OF RAILWAYS.}

President's Address Delivered at the Amual Meeting of the American Academy of Railway Surgeons, at Chicago, Ill., Oct. 6-8, 1897.

BY L. E. LEMEN, M.D.

DIVISION SERGEON LNION PACIRIC SYSTEM, I)ENVER, COLO.

CONNECTION BETWEEN LAW AND MEDICINE.

Law and medicine, like "knowledge and wisdom," are "far from being one," but here Cowper's distinction ceases to apply, for the connection between the two professions is close and intimate, and each new discovery in this age of rapid, scientific progress unites more closely these great branches of learning. Med. ical jurisprudence has widened far beyond testamentary capacity, commissions in lunacy and expectation of life. The toxicologist and the chemist are quite commonly assistants of both commonwealth and accused in capital trials; the surgeon, the bacteriologist and the biologist are hand in hand with attorney and counsellor in civil and criminal causes. Where the Green Bag or the London Lancet was once filed alone, the Medico-Legal Journal now shares shelf space and attention, and the journals of both professions devote much printed space to medical jurisprudence and medico-legal surgery.

The Medico-Legal Society, from an insignificant local association, has grown to be an international organization; strong numerically, stronger intellectually, strongest in original research and investigation; throwing light upon problems which have heretofore puzzled alike the disciples of Blackstone and of Fsculapius, including in their numerous courses of study every subject of common interest, from psychics and hypnotism to compulsory vaccination; from toxicology to our own branch of railway surgery.

POPULAR HOSTILITY TO RAILROADS AND THEIR SURGEONS

It is popular and profitable to criticise the grinding railroad monopolist in print and on the platform; it is politic in a court room to sneer at the salaried surgeon who has given his best and most conscientious professional services, often under unfavorable and distressing conditions as a "corporation tool and hireling" whose testimony, "well, gentlemen of the jury, you know what expert testimony is worth, especially when the expert has a life position with the corporation. I leave it to your own common sense." In the determined effort to dominate the minds of twelve men, sometimes unintelligent, often uninformed, always 
uncertain, courtroom proceedings in railroad cases too frequently degenerate into oratorical appeals, which utterly disxegard the underlying, unchanging principle of justice, to be applied witheut fear or favor to individuals as well as to corporations.

LUMANE PROVISIONS MADE BI CORPORATIONS.

Corporations, like individuals, though born in sin, are not totally depraved. A critical public may attribute them to policy and self-interest, nevertheless the fact remains that the legally and proverbially soulless rail. way corporations make more and better provisions for accident and emergency cases than individual employers and partnerships engaged in business equally hazardous. The emergency case with bandages, etc., in each engine, the stretcher in every station (Pa. R.R.), the ambulance in large cities, the hospital owned, equipped and operated by the company (U.P. R'y.), or the hospital to which the company makes an annual donation in consideration of care for injured employes, accident and emergency cases ( $\mathrm{Pa}$. R.R.), the salaried surgeons at central points, and the rural practitioners whose infrequent services are compensated by a regular "annual" (Pa. R.R., Reading R.R.), all are active agents for the alleviation of the ills of humanity, though the public deny their principal the credit of putting them in action for humanity's sake.

RELIEF DEPARTMENT, ETC.

Is it solely for the benefit of the company that relief departments are organized with sick and death benefits for employes, whether the illness or death results from accident or from natural causes? Is it solely for the company's benefit that surgical attendance is furnished during disability from accident in the company's service; that trusses, artificial limbs, etc., are supplied for injured employes, that pensions are planned for old age?

Certainly the relief department contract bars the beneficiary from bringing suit against the company. But for the numerous accidents caused by his own negligence or the negligence of his co-employes, the employe had no legal right of action. Yot in both these instances the relief department pays the monthly disablement benefits for a year or more (Pa. R.R., Reading R.R.)

NECESSITY FOR RAILWAY PRACTITIONER AS A SPECIALIST,

To reiterate a truism, railroading is a hazardous occupation. Though the greatest possible care be observed, though the latest improvements be used, some accidents are inevitable, some collisions are sure to occur; trainmen are as surely predisposed to certain diseases as glass cutters or workers in emery. Higher rates of speed, lenuthening miles of track, increasing forces of train workers strengthen and render imperative the necessity for an intelligent body of medical men who make railroad practice a specialty. The opinions of a fickle and often wholly unreasonable public have small place and smaller influence in a profession which listens to the first cry of the living and the last moan of the dying, and hears through all its years of active service only the wails, the woes and the weaknesses of humanity. Medical men have no time to reply to healthy critics. The sick must be healed, the helpless must be strengthened, the mangled must be relieved, and whether he be oculist or neurologist, gynecologist or railway surgeon, the man who gives his best services to the sick and dying is accountable to his own conscience, and to that only, whether his compensation be the check of a corporation or an individual, gold from a bank or silver from a stocking, or whether such compensation never comes at all.

RAILWAY SURGEON HONEST RATHER THAN INTERESTED WITNESS

No individual seeking to perpetrate a fraud upon a railroad company through an eloquent appeal to the sympathies and prejudices of a jury, and the complaisant testimony of irresponsible physicians with an eye single to the enlargement of their private practice, has a right to expect any evidence from a railway phy. sician but the truth. And no general manacrer, no division superintendent, no relief department, no board of directors, no corporation, seeking to perpetrate a fraud against an individual through pressure upon salaried employes has a right, because of salary paid for medical services, to any testimony from a railway surgeon save "the whole truth and nothing but the truth."

ANOMALOUS POSITION OF RAILWAY SURGEON AS A WITNESS. THREE-FOLD RELATION.

In hospital or home, in collision or office examination, the railway surgeon is as other physicians, but as a witness in actions against the railroad by persons who claim to have been injured through the company's negligence, his position is strikingly anomalous:

1. He is the employe of the defendant railroad in whose behalf he is called to testify.

2. He was the physician of the plaintiff against whom or by whom he is called to testify at the period most in controversy. Further, this professional relation was many times initiated under circumstances which gave the plaintiff no option save death or acceptance of the railway surgeon's services, and sometimes a merciful insensibility deprived him of any option whatsoever.

3. $\mathrm{He}_{e}$ is called by the defendant company as an expert witness in thoir behalf.

The difficulties of this three-fold position are selfevident, the responsibilities definitely aligned, the duties not so clearly defined.

Having survived the omniscience of youth, the writer submitted the following hypothetical yuestion to ten physicians and ten attorneys, equally divided in numbers as to affiliations with or against corporations.

What do you, as a physician (or attorney), think a railroad company has the right to expect from an attending physician in their employ, as witness in an action brought against the railroad for injuries alleged to have beon received through the company's negligence?

Twenty unqualified declarations for the "whole truth and nothing but the truth," are followed by varying comments on statutory regulations concerning medical witnesses, and by criticisms of railway influtnce on supreme courts, and of juries for unjust rerdicts against companies in obedience to popular clamor.

$$
\text { AS MEDICAL EXAMINER. }
$$

There can be no question that if the railway physician comes in only as medical expert for the company, having examined the plaintiff in that capacity, he is at liberty to tell anything he learns from such examination.

AS ATTENDING PHYSICIAN. LEGAL BARRIERS.

If he be called by the company as the surgeon who attended the plaintiff at the time of the accident or disablement, in many States his lips are sealed by ex- 
press statutory enactment forbidding physicians to sional and individual honor, and that the company divulge facts learned in the course of professional sought only truth and justice in the case, would service. Others effect the same object by not permit- prove of financial advantage to the corporation, lesting physicians to divulge facts which would be a bar sen the number of suits brought, decrease the amount to the patient in a subsequent civil action. (Penn, etc.)

On the other hand, membership in a relief department commonly includes contractual renunciation of the right of action; hence, for a large body of employes, the surgeon's testimony is not needed. The written law of at least one (Col. State Statutes) State, however, expressly prohibits contracts (conflicting interests) between corporations and their employes, which relieves the company from liability for accidents caused by the negligence of the corporation or its servants, and pronounces such contracts null and void. Here the railway surgeon comes in as the necessary and most responsible witness on both sides, as he must needs be, in many cases where the plaintiff is an injured passenger.

PROFESSIONAL DUTY.

His duty to his profession requires that he state the facts so simply that the non-professional juror may understand; so accurately that his brother physicians may recognize their physiologic correctness, gather helpful ideas from novel and peculiar cases, and hints for future testimony.

PROFESSION AND DUTY THERETO FIRST, RAILWAY EMPLOYMENT SECONDARY AND INCIDENTAL.

The matter of salary has no bearing on the subject. From his student days till his hands are stilled, the surgeon cheerfully gives the same skill to the poor that the rich receive for large reward. The great and beneficent discovery of his life is not patented like an air brake or a car coupler, but freely given to humanity through printed and professional channels. $\mathrm{He}_{\theta}$ is first and always a physician; the railway employment is only an incident; if it terminated he would still be physician and surgeon. It follows that the duty to himself, his profession and his patient, is his highest duty, and no railroad company or its attorney has any right by suggestion, intimidation, or, in any manner whatsoever to seek the suppression of the facts in the case as the attending surgeon believes them to be.

"Keep your eyes and ears open and your mouth shut," is an excellent rule in the ordinary line of duty, for hospitals, and in the confusion of accidents and emergencies, but to expect a physician to keep silent when duty demands and the law lays upon him an obligation to speak, is to suggest indirectly that he is the unhappy possessor of a strabismic or an astigmatic conscience.

\section{RELEASE BY COMPANY.}

Where the facts and circumstances are against the company's interest it is quite as much the attending surgeon's legal and moral duty to disclose them as where an unscrupulous plaintiff seeks by fictitious ailments and symptoms to procure an award against the company to which he is in no way entitled. If his view of "the whole truth and nothing but the truth" conflicts with the company's interest, the attending railway surgeon should be altogether released and relieved from acting as a witness in their behalf. The novel spectacle of a railway surgeon testifying against his employing company would certainly be unprofitable to the corporation in the first instance; but in the long run, the self-evident facts that the surgeon employed maintained his profes. to a wage-earner he can estimate with considerable 
accuracy. He has two eyes as well as two ears. A bone, a lead pencil, and a twisted piece of paper sometimes double the chance of success. Object teaching is the natural method; demonstrate the facts where practicable.

2. Avoid controversies with the cross-examiner. The war is unprofitable because unequal; he can strike when the surgeon is down; his last turn with court and jury comes when the medical man is no longer an active participant in the case.

3. Keep sweet. He who loses his temper loses his cause. Questions are frequently asked for the express purpose of irritating the surgeon; an exhibition of anger is the very result desired, and the first ruffling of composure is welcomed as a successful assault on the enemy's works.

4. Talk slowly; take time to answer questions fully. Minds untrained in medical lore can not follow and comprehend professional explanations at the same rate of speed as assistants at a clinic.

One of the most common methods of perplexing a witness and neutralizing the effect of his testimony is to fire volleys of rapid questions at him. Half finished, hastily given answers create erroneous and contradictory impressions; hence the necessity for deliberation throughout expert testimony, and an utter disregard of attempts to undo the surgeon through undue haste.

5. Answer the question asked. $\mathrm{He}$ who volunteers information or explanation digs a pit into which the cross-examiner shall shortly but surely tumble him. In the infrequent instances where "yes" and "no" will not suffice as answers, an explanation of the crossexaminer's ingenious verbal trap will be developed by questions of opposing counsel on re-direct examination, or will be permitted upon request to the court for opportunity to make the matter clear.

6. Answer briefly. The best approved judicial proceedings are in accord with the petitions of those Indian Territory negroes who habitually besought the Judge of all hearts to grant them "long prayers and short answers." The plaintiff in his complaint or declaration "ever prays," and the defendant in his answer "will ever pray," at considerable length and with much technical repetition, but that surgeon most helps his cause who in his testimony gives short answers and shuns technicalities.

7. Say, "I do not know." The surgeon who knows everything is clay in the hands of the cross-examiner, and malformed or formless clay in the verdict of the jurymen.

8. Do not discount the medical information possessed by the cross-examiner. Thousands of lawyers beside Lord Eldon have studied medicine before reading law. Lacking a medical education, the lawyer prepares his case by repeated consultations with leading physicians, by reading articles in medical journals and by careful examination of the accredited medical authorities.

As was recently said by a distinguished New York attorney in addressing the graduating class of a great medical school, "The medical profession differs from the legal in the fact that the physician is not expected to know law, but the lawyer must have a familiar and comprehensive knowledge of medicine."

JOINT AIMS AND AOHIEVEMENTS OF MEDICINE AND LAIV. \begin{tabular}{l|l} 
LAW. & aged expectantly, than the lesions of the \\
Personally the doctor may never need the lawyer's & are now subjected to surgical treatment.
\end{tabular} services, though the attorney is sure to require the physician's ministrations; but professionally the advocate who fights against oppression is the blood comrade of the physician who battles against death. Together they have warred for the rights of the poor, the helpless and the despised; together they have defied kings and corporations. When, in the dark ness of the middle ages, all other good seemed lost, the doctor and the barrister stood alone as mouthpieces and interpreters of the common people--soli. tary champions of liberty and justice, unconquered and unterrified by kings. In our own day, through their joint efforts, boards of health have been organized, State and Government inspection of water and food products introduced, reformatories and insane asylums reconstructed, prison conditions ameliorated and upheaved, and many other great reforms instituted.

HIGH MORAL STANDARD DEMANDED OF PHYGICIAN AND ATTORNEY.

There can be no human liberty without law; there can be no healthy human liberty without medicine; the tyranny of rulers and the tyranny of disease alike reduce men to slavery. "Noblesse oblige," said the old French king, and he who breaks these shackles from humanity must regard neither men nor money, neither position nor power. Leprosy and smallpox are less to be dreaded than the moral contagion of dishonor. Whether in clinic or court room, whether beside the sickbed or before the bar, temporizing, policy, the "necessity" which Pitt called " the argument of tyrants" and "the creed of slaves," are only weights he he has laid aside. His rule of life is the Supreme Law enunciated by the Great Healer: "Ye shall know the truth, and the truth shall make you free;" and his earthly ambitions are summed up in. Wolsey's counsel to Cromwell:

"Be just and fear not.

Let all the ends thou aims' $t$ at be thy country's, Thy God's, and truth's, then if thou fall'st, O Cromwell, Thou fall'st a blessed martyr."

-Shakspeare, Henry VIII; Act III: Sc. 2.

\section{THE SURGERY OF THE BRAIN.}

Address delivered before the Austin Flint Medical Society, Cloar Lake, Ia., July 20, 1897 .

BY ALBERT I. BOUFFLEUR, B.S., M.D.,

Professor of Anatomy and Clinical Surgery, Northwestern University Woman's Medical School; Demonstrator of Operative Surgery, Rush Medical College; Attending Surgeon Cook County Hospital, etc.

CHICAGO, ILL.

The surgery of the brain and its membranes has within the last two or three years received more merited attention than during the preceding decade, when the great surgical world spent a large portion of its energy on that important class of diseases which are found in the abdomen and which are now so generally subjected to surgical treatment.

All subjects which directly affect the life of an individual are of special interest to the conscientious physician and certainly there is no class of diseases which are more obscure in their symptomatology, more erratic in their course, more discouraging in their treatment or more uniformly fatal, when managed expectantly, than the lesions of the brain, which
are now subjected to surgical treatment. 